\title{
Prevalence of MTHFR C677T and A1298C Mutations and Thrombophilia in Puerto Rico
}

Raul H. Morales-Borges*

American Red Cross, PR Region, USA

\section{Objectives}

To determine the prevalence of MTHFR mutations in the Puerto Rican population and their relationship with thrombophilia. To determine if there are other risk factors that can worsen the risks for arterial and venous thromboembolisms in that population.

\section{Background}

The methylenetetrahydrofolate reductase (MTHFR) is coded by the gene with the symbol MTHFR on chromosome 1 location p36.3 in humans and there are DNA sequence variants (genetic polymorphisms) associated with this gene, although the two most common ones are C677T and A1298C. Deficiencies in production or function of this enzyme have been associated with increased risk of myocardial infarctions, stroke, venous thrombosis, several types of cancer, congenital defects, inflammatory bowel disease, and several neuropsychiatric conditions. It has been found at high frequencies in Europeans and American Caucasian population. In particular, the C677T polymorphism shows a wide regional and ethnic variation. Homozygosity (TT) among Whites is 6-14\%. In African populations and in Blacks living outside of Africa such as in Brazil and in the United States, the frequency falls to less than $2 \%$ for the TT variant. The prevalence rises in Mediterranean and Hispanic population. For example, among Hispanics in prevalence ranges as high as $21 \%$. The A1298C mutation, on the other hand, does not show as much population variance; its prevalence is more uniform within the currently studied groups. One study demonstrated that the high frequency of the C677T/C677T and C677T/ A1298C genotypes that are found in Hispanics may contribute to a wide spectrum of anomalies, especially in population subject to poor nutrition and low folate intake.

\section{Study Proposed}

Cross-sectional Retrospective Review Study of medical records of patients with MTHFR within Puerto Rico with the collaboration of physicians that have identified those cases either as outpatient or inpatient.

\section{Method and Results}

A revision of 2914 active medical records from patients in an ambulatory solo-practice of community-based mixed hematology and medical oncology physician was done. 179 patients have been identified with hypercoagulable states (thrombophilia) for a prevalence of $6.14 \%$. A random cross-sectional selection of $10 \%$ of the 179 patients was done for total of 18 cases. MTHFR mutations were identified in 7 out of 18 cases for a prevalence of 39.89\% of which 4 (57.14\%) were homozygous for 2 copies of C677T, 2 (28.57\%) homozygous for 2 copies of A1298C, and 1 (14.29\%) heterozygous for 1 copy of C677T and 1 copy of A1298C. Most of them are women. Their age have a range from 17 to 48 with a mean of 39. All cases of MTHFR mutations had normal serum homocysteine levels. The thrombotic events recorded in them were recurrent miscarriage syndrome (3/7), deep venous thrombosis (3/7), and transient ischemic attack (1/7). Only two cases had MTHFR mutation as the only hypercoagulable state and five cases had other coexistence conditions such as anti-thrombin III deficiency, protein C and S deficiencies, Lupus Anticoagulant, and factor V Leiden mutation.

\section{Discussion}

Our study sample was small but this is the first puertorrican data published and it is concordant with the published data that states the MTHFR C677C among Hispanics may be higher than in other reported groups. The only discrepancy is that in our group all had normal serum homocysteine levels. It's important what few studies said; the different genotypes between arterial and venous thrombosis and their prevalence may have a crossover and can vary. So, a complete and larger study is needed to distinguish the real difference or crossover between the genotypes, the serum homocysteine level, the personal thromboembolic event, and their family history. 
Citation: Morales-Borges RH (2014) Prevalence of MTHFR C677T and A1298C Mutations and Thrombophilia in Puerto Rico. J Blood Disorders Transf 5: 213. doi: 10.4172/2155-9864.1000213

PPT 1

Prevalence of MTHFR C677T and A1298C mutations and thrombophilia in Puerto Rico

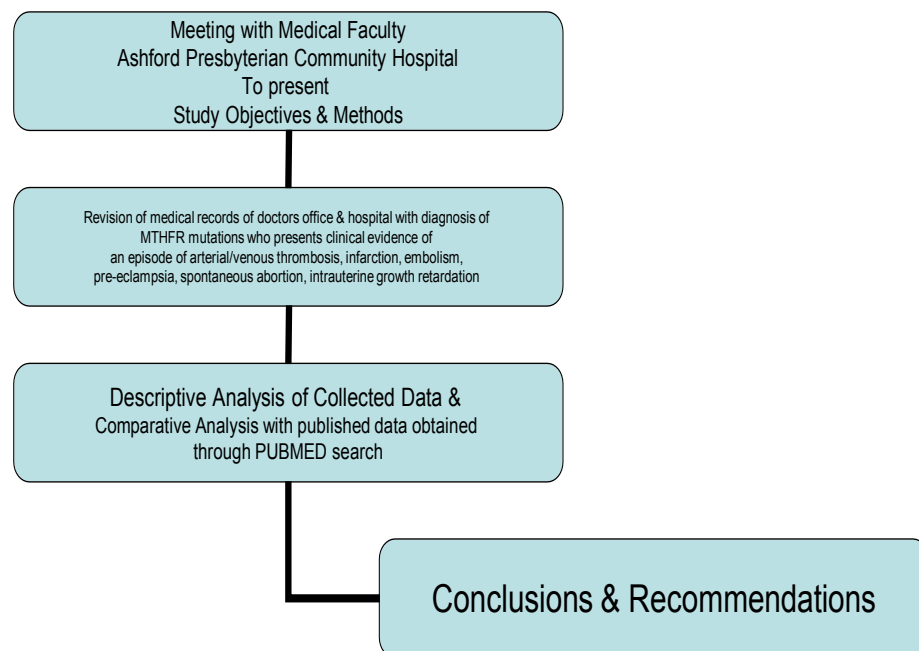

PPT 2

\section{MTHFR C677T:}

\section{5,10-Methylenetetrahydrofolate Reductase (F 5-Methyl-Folate)}

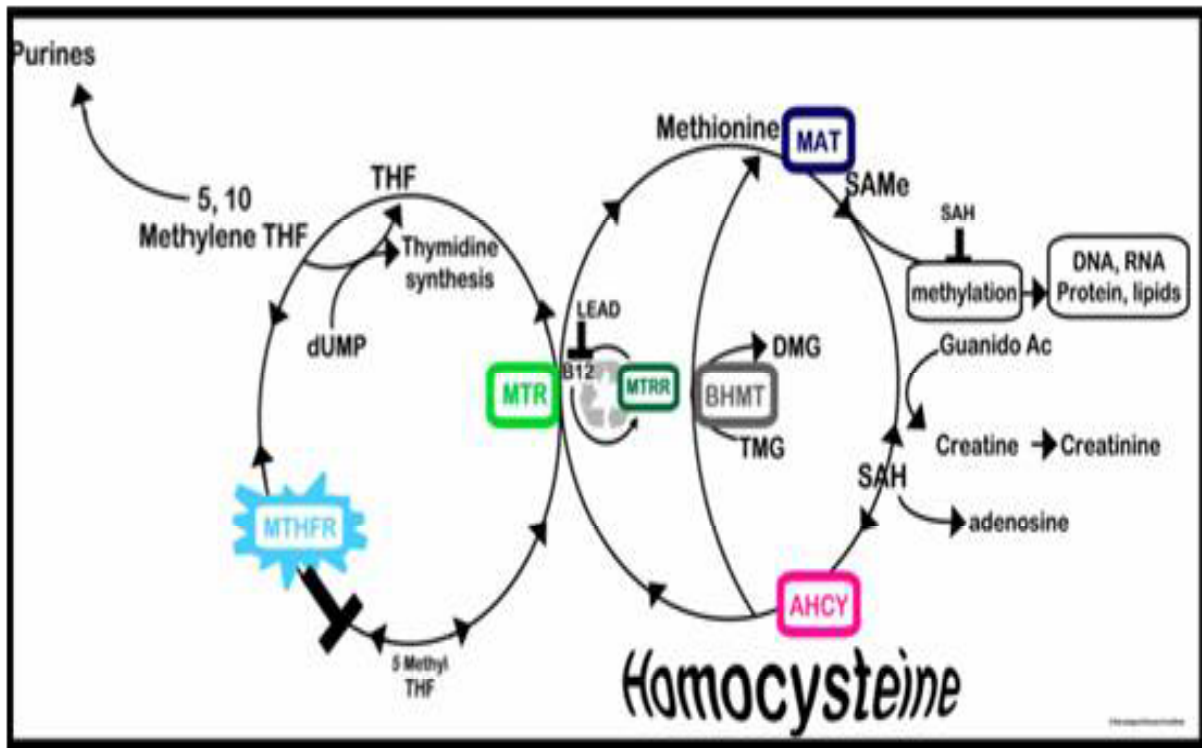


Citation: Morales-Borges RH (2014) Prevalence of MTHFR C677T and A1298C Mutations and Thrombophilia in Puerto Rico. J Blood Disorders Transf 5: 213. doi: 10.4172/2155-9864.1000213

\section{PPT 3}

Table 1: Published expert consensus recommendations available evaluating the utilization of MTHFR C677T testing for thrombosis and inherited thrombophilia

\begin{tabular}{|c|c|c|c|c|}
\hline $\begin{array}{c}\text { Professional } \\
\text { Organization }\end{array}$ & Year & $\begin{array}{c}\text { Type of Clinical } \\
\text { Consensus } \\
\text { ACMG }\end{array}$ & $\begin{array}{c}\text { Recommendations } \\
\text { for stand-alone } \\
\text { MTHFR C677T } \\
\text { testing? }\end{array}$ & $\begin{array}{c}\text { Reflex testing in presence } \\
\text { of elevated serum } \\
\text { homocysteine (>13 umol/L)? }\end{array}$ \\
\hline ACOG & 2001 & $\begin{array}{c}\text { Working Group } \\
\text { Consensus } \\
\text { Statement }\end{array}$ & No \\
\hline CAP & 2001 & $\begin{array}{c}\text { Practice Bulletin } \\
\text { Guideline }\end{array}$ & No \\
\hline AHA & 2002 & $\begin{array}{c}\text { Expert Consensus } \\
\text { Recommendation }\end{array}$ & No & No \\
\hline ACCP & 205 & $\begin{array}{c}\text { Expert } \\
\text { Recommendation }\end{array}$ & No & Yes-optional \\
\hline BHSC & 2008 & Clinical Guideline & No & No \\
\hline
\end{tabular}

ACMG: American College of Medical Genetics; ACOG: American College of Obstetrics and Gynecology; CAP: College of American Pathologist; AHA: American Heart Association; ACCP: American College of Chest Surgeons; BHSC: British Hematology Standards Committee; MTHFR: Methylene TetraHydroFolate Reductase

\section{PPT 4}

Table 2: Patients with MTHFR Mutations in Our Study

\begin{tabular}{|l|l|l|l|l|l|}
\hline Number & Sex & Age & Hyper-coagulable state & Thrombotic event(s) & Co-Morbid Condition(s) \\
\hline 1 & F & 17 & $\begin{array}{l}\text { MTHFR homo 2 copies } \\
\text { C677T }\end{array}$ & Transient Ischemic Attack & Oral Centraceptive Pills \\
\hline 2 & F & 33 & $\begin{array}{l}\text { MTHFR, 2 copies A1298C } \\
\text { \& Prot S def }\end{array}$ & $\begin{array}{l}\text { Recurrent Miscarriage Syn- } \\
\text { drome }\end{array}$ & None \\
\hline 3 & F & 26 & $\begin{array}{l}\text { MTHFR 2 copies C677T \& } \\
\text { Lupus Anticoagulant }\end{array}$ & $\begin{array}{l}\text { Recurrent Miscarriage Syn- } \\
\text { drome }\end{array}$ & None \\
\hline 4 & M & 48 & $\begin{array}{l}\text { MTHFR homo 2 copies } \\
\text { C677T }\end{array}$ & $\begin{array}{l}\text { Deep Venous Thrombosis } \\
\text { of leg }\end{array}$ & $\begin{array}{l}\text { Left knee arthroscopic } \\
\text { surgery }\end{array}$ \\
\hline 5 & F & 38 & $\begin{array}{l}\text { MTHFR 1 for C677T \& } \\
\text { A1298C plus ATII, Prot } \\
\text { C\&S def }\end{array}$ & $\begin{array}{l}\text { Recurrent Miscarriage Syn- } \\
\text { drome and Angina Pectoris }\end{array}$ & None \\
\hline 6 & F & 42 & $\begin{array}{l}\text { MTHFR 2 copies C677T } \\
\text { Factor V Leiden }\end{array}$ & $\begin{array}{l}\text { CNS Venous Sinus Throm- } \\
\text { bosis }\end{array}$ & None \\
\hline 7 & F & 32 & $\begin{array}{l}\text { MTHFR 2 copies for } \\
\text { A1298C \& ATIll def }\end{array}$ & $\begin{array}{l}\text { Internal Jugular Vein Throm- } \\
\text { bosis }\end{array}$ & None \\
\hline
\end{tabular}




\section{PPT 5}

\section{Laboratory Evaluation}

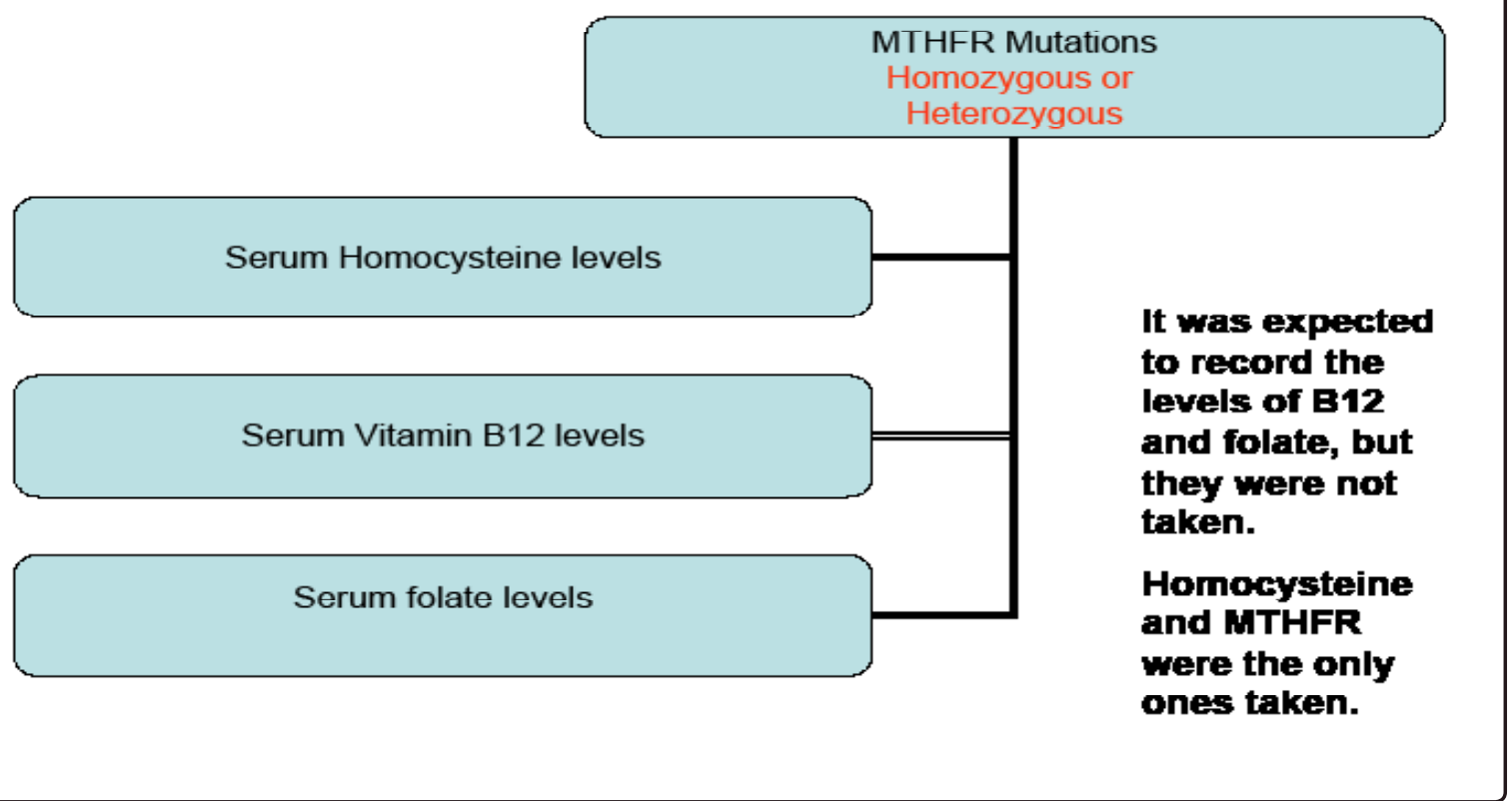

PPT 6

\section{Investigation of Associated Thrombophilia to MTHFR Mutations}

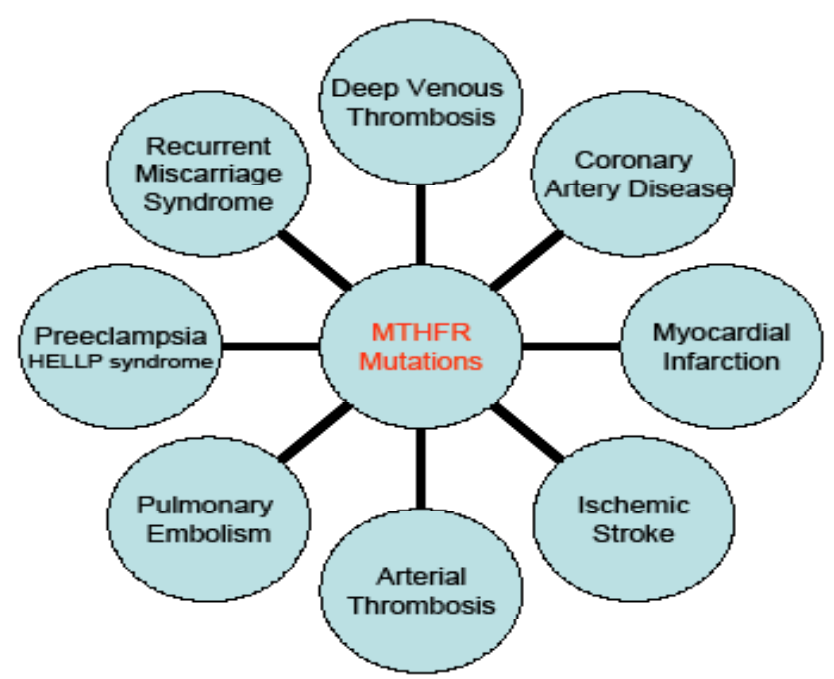

They were investigated as part of history review of the medical record, but sample was small. They needed to be further investigated. 


\section{PPT 7}

\section{Recommendations}

\section{We Need to Study the Relationship \& Crossover of the Following in Puerto Rico}

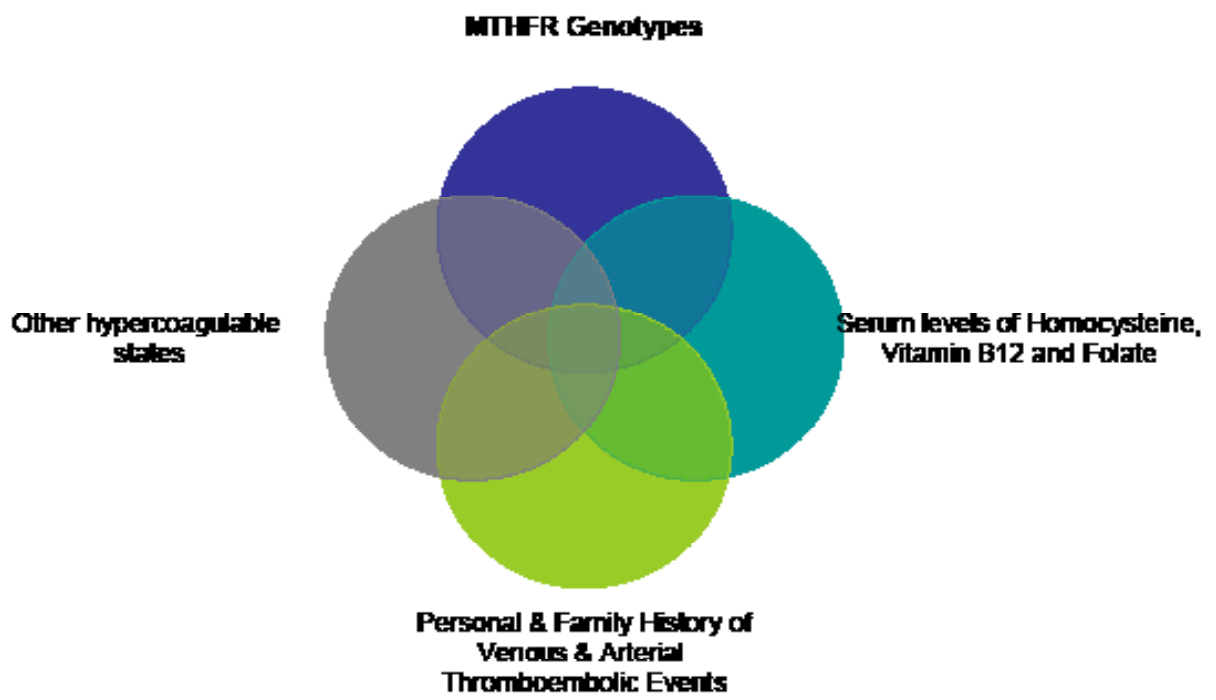

\section{Conclusions}

The prevalence of the MTHFR mutation was $40 \%$ approximately with $57 \%$ for the C677T mutation.

It is more frequent in women and they present more with venous thrombosis such as recurrent miscarriage syndrome and deep venous thrombosis.

$70 \%$ of the cases of the MTHFR mutations co-exist with another ones such as Factor V Leiden mutation, Lupus Anticoagulant, and Deficiencies of Anti-Thrombin III and/or Protein C \& S.

\section{References}

1. Castro R, Rivera I, Ravasco P, Camilo ME, Jakobs C, et al. (2004) 5,10-methylenetetrahydrofolate reductase (MTHFR) 677C-->T and 1298A-->C mutations are associated with DNA hypomethylation. J Med Genet 41: 454-458.

2. Chowdary D, Streck D, Schwalb MN, Dermody JJ (2003) High incidence of two methylenetetrahydrofolate reductase mutations (C677T and A1298C) in Hispanics. Genet Test 7: 255-257.

3. Falcon CR, Cattaneo M, Panzeri D, Martinelli I, Mannucci PM (1994) High prevalence of hyperhomocyst(e)inemia in patients with juvenile venous thrombosis. Arterioscler Thromb 14: 1080-1083.

4. Hanson NQ, Aras O, Yang F, Tsai MY (2001) C677T and A1298C polymorphisms of the methylenetetrahydrofolate reductase gene: incidence and effect of combined genotypes on plasma fasting and post-methionine load homocysteine in vascular disease. Clin Chem 47: 661-666.

5. Isotalo PA, Donnelly JG (2000) Prevalence of methylenetetrahydrofolate reductase mutations in patients with venous thrombosis. Mol Diagn 5: 59-66.

6. Mack R, Chowdary D, Streck D, Dermody J (1999) Inherited thrombophilia genes in minorities. Genet Test 3: $371-373$.

7. Wu AH, Holtman V, Tsongalis GJ, Macer J (1999) Homocysteine screening of a female Hispanic population. Int J Mol Med 4: 295297. 